\title{
RESULTS OF SUNFLOWER BREEDING IN RESISTANCE TO BROOMRAPE ON DON
}

\author{
Gorbachenko, F.I. , Usatenko, T.V., Gorbachenko, O.F.
}

State Research Institution, Donskaya experimental station by L.A. Zhdanov State Scientific Institution All-Russia Research Institute Oil Crops (VNIIMK) by V.S Pustovoit, Rostov Region, Azovsky District, Oporny village

Received: September 10, 2010 Accepted: May 25, 2011

\section{SUMMARY}

Results of long term research (1925-2009) on sunflower breeding in resistance to broomrape in Don Region are hereby presented. The most virulent population of Orobanche cummana Wallr. has been found in north-western part of Rostov region. Recommendations for reducing loss in sunflower yield caused by broomrape are given.

Key words: sunflower, broomrape, breeding, varieties, hybrids, self-pollinated lines, virulence, commercial fields

\section{INTRODUCTION}

Broomrape, Orobanche cumana Wallr., is a plant parasitizing on sunflower root system. Broomrape exhausts all nutrients and water from the roots of other plants, and as a result the plants become weaker and lose turgor which leads to decrease in crop capacity, worsening of commercial seed quality and in the most severe cases even to crop failure.

Different scientists, such as botanists, physiologists, breeders, have considered the problem of the broomrape harmfulness (Caspary, 1854; Koch, 1887; Byalosuknya, 1919; (cited according to Byalosuknya, 1930); Rihter, 1928; Nechiporovich, 1929; Pushkareva, 1930; Beylin, 1930; Novopokrovsky, 1930; Pustovoit, 1926; Zhdanov, 1927, 1930 and etc.).

These scientists stated that sunflower and broomrape are in the continuous process of evolution as "host and parasite". Due to that fact the sunflower breeding to be resistant to broomrape is carried permanently.

* Corresponding author: Phone: (863)247-74-53, Fax: (86342) 75-121, e-mail: post@dos-vniimk.ru 


\section{MATERIALS AND METHODS}

In the beginning of the systematic scientific breeding in Russia of sunflower varieties the situation was as following: varieties resistant to broomrape populations existing in those years were developed with the help of method of individual selection (years 1910-1912). Those were for example: Saratovsky 169, Saratovsky 206, (Plachek, Steboot, 1915) and Kruglik A-41 (Pustovit, 1926) varieties.

These varieties were widely cultivated. They took the leading position in areas of sunflower cultivation. The problem of broomrape seemed to be solved.

As Zhegalov (1924), noted, the creation and introduction into production of broomrape-resistant sunflower varieties made it possible to remove from the agenda further efforts to fight against this parasitic plant. But in the early and mid 1930's, in a number of southern USSR areas there was a difficult situation with sunflower cultivation as the crop was massively infected by broomrape. This major oil-bearing plant was under serious threat and could have disappeared as an agricultural crop. In 1925, faced with such conditions of the crop, Zhdanov started selection of sunflower in Don experimental station, established in 1924.

The inspections of industrial crops, held under supervision of Zhdanov in a number of areas, showed that all previously developed varieties and landraces, as well as samples from the world collection were affected by broomrape, and in some cases it led to full crop failure. As noted by Pustovoit (1970), Zhdanov established the reason why the sunflower varieties were affected by broomrape independently from the works of experimental station "Kruglik".

\section{RESULTS AND DISCUSSIONS}

As a result of these studies he found that different physiological races of broomrape parasitized on sunflower roots. They were named A and B. Moreover, broomrape $\mathrm{B}$ was more severe and it infected $100 \%$ of all the previously developed varieties. For the first time the significant parental germplasm material of sunflower was collected in the Rostov region.

Zhdanov managed to find individual plants which were broomrape-resistant during the inspection of sunflower crops in Andreievsky and Oktyabrisky district of the area of Mariupol (Donetsk region of Ukraine). By Applying method of breeding to the plot heavily and artificially sown with broomrape seeds, Zhdanov determined, for the first time, broomrape-resistant sunflower plants which became parental material for such varieties as Zhdanovsky 6432, Zhdanovsky 8281 and Stepnyak. In the following years these varieties were sown on more than 1 million hectares. Production launch of these and other varieties created considerable increase the yield of sunflower, especially in broomrape infected areas, thus expanding areas under the crop and restoring it as an agricultural crop. 
It was proven, that sunflower can give high yield of seeds and provide the oil production industry with raw material.

Such favourable conditions for sunflower cultivation existed for the period of 35-40 years. Crop rotation, usage of broomrape-resistant crops for sowing and performance of the scientifically-proven technologies of cultivation allowed farmers to receive yield in all areas of sunflower cultivation.

In the period between 1970 and 1974 new signals of broomrape infected areas appeared. The inspection of the fields in the region that we carried out as well as the evaluation of varieties sown in areas infected by broomrape proved the appearance of new, more severe broomrape races (Gorbachenko, Mezinova, 1985; Gorbachenko, Shurupov, 1991). Disorder in crop rotation influenced greatly the process of appearance of new broomrape races and their rapid spreading. Over the years, on separate farms, sunflower occupied up to $20 \%$ in crop rotation and it led to rapid broomrape spreading and infection of the vast production areas.

The threat of decrease in sunflower crops caused by more virulent broomrape races formed a necessity of creation of resistant genotypes to this parasitic plant. In 1974 methodical research started at the station and in the special field nursery where more than $30 \mathrm{~kg}$ of broomrape seeds which had been collected in different areas of sunflower cultivation, were sown on 1 hectare. Annually this field nursery was infected with seeds of more virulent broomrape races, collected in different regions of Russia and Ukraine. Variety Kruglik A-41, which was resistant to the races $A$ and $B$, was used as varieties-indicator. During the inspection of the field nursery it was established that all examined sunflower varieties were infected by the new broomrape races in various degrees (Table 1).

Table 1: Sunflower infected by new broomrape races (infected background), (Donskaya experimental station, 1976).

\begin{tabular}{lccc}
\hline \multirow{2}{*}{ Variety, No } & $\begin{array}{c}\text { Quantity of broomrape flower stalks } \\
\text { on 100 plants, pieces }\end{array}$ & \multicolumn{2}{c}{ Broompare affection } \\
\cline { 3 - 4 } & 2984 & 80 & degree \\
\hline Zenit & 3192 & 80 & 37.3 \\
385 & 3311 & 70 & 47.3 \\
Kirovogradsky & 5180 & 100 & 51.8 \\
Donskoy nizkorosly 47 & 4949 & 90 & 56.1 \\
Zelenka 368 & 5400 & 90 & 60.0 \\
Armavirsky 3497 & 6080 & 100 & 60.0 \\
Mayak & 4912 & 80 & 61.4 \\
1141 & 6300 & 100 & 63.0 \\
Peredovik & 4410 & 70 & 63.0 \\
319 & 5224 & 80 & 65.3 \\
6843 & 7230 & 100 & 72.3 \\
VNIIMK 8883 & 9157 & 100 & 91.6 \\
Kruglik A-41 (control) & &
\end{tabular}


Considering the dominant character of inheritance of broomrape-resistance, the sunflower plants, affected to a lesser degree, were put into paper isolator bags for self-pollination, intracultivar (intra-line) and intervarietal (inter-line) pollination. It was established during the study that the most effective and productive method of reception of broomrape forms was self-pollination of sunflower plants on the infected plot. As inbreeding leads to genetic differentiation of parental material, after three years of work we managed to get inbred lines, on which broomrape practically had no harmful effect.

Further selection work was also carried out on the infected background. We picked out the plants with high resistance to this parasitic plant from the segregated populations. So, in 1976210 elite plants were picked out from the early-ripening sunflower varieties. Subsequent estimation and selection of generations of plants grown on the infected plot in the field conditions as well as their repeated estimation during the autumn-winter period in a greenhouse, in accordance to Panchenko (1975), method increased resistance of these selections to more aggressive broomrape races from $4.2 \%$ up to $88.6 \%$ by 1982 .

Simultaneously economic traits of progeny of the chosen elite plants were being studied on the testing plots. Their reproduction was held on the space isolated plots by directed pollination. This methodical and practical research allowed us to get new, promising initial material with high (80-100\%) resistance to a complex of broomrape races and with economically valuable traits (Table 2 ).

Table 2: Description of the best broomrape-resistant sunflower selections (Donskaya experimental station, 1981-1983).

\begin{tabular}{|c|c|c|c|c|c|}
\hline \multirow{2}{*}{ Selections } & $\begin{array}{l}\text { Vegetation } \\
\text { period }\end{array}$ & $\begin{array}{l}\text { Seed } \\
\text { yield }\end{array}$ & $\begin{array}{l}\text { Seed oil } \\
\text { content }\end{array}$ & Oil yield & $\begin{array}{l}\text { Broomrape affec- } \\
\text { tion(infected plot) }\end{array}$ \\
\hline & Days & $\mathrm{t} / \mathrm{ha}$ & $\%$ & $\mathrm{t} / \mathrm{ha}$ & $\%$ \\
\hline \multicolumn{6}{|c|}{ Early-ripe group } \\
\hline 5714 & 93 & 2.94 & 48.4 & 1.33 & 4.2 \\
\hline $3 / 174$ & 96 & 2.91 & 51.5 & 1.42 & 7.4 \\
\hline 5841 & 96 & 2.83 & 48.0 & 1.27 & 1.3 \\
\hline 9061 & 93 & 2.73 & 50.5 & 1.30 & 0.0 \\
\hline Zenit (standard) & 97 & 2.66 & 52.7 & 1.32 & 94.8 \\
\hline $\mathrm{NSR}_{095}$ & & 0.18 & & & \\
\hline \multicolumn{6}{|c|}{ Mid-season group } \\
\hline 10565 & 100 & 3.02 & 52.1 & 1.50 & 3.3 \\
\hline 10470 & 101 & 2.90 & 51.1 & 1.41 & 0.0 \\
\hline 10537 & 99 & 2.85 & 50.8 & 1.37 & 0.0 \\
\hline Mayak (standard) & 103 & 2.72 & 52.2 & 1.35 & 99.7 \\
\hline $\mathrm{NSR}_{095}$ & & 0.21 & & & \\
\hline
\end{tabular}

Over the next years the plot infected with broomrape was used for estimation, hybridization and breeding of new parental material resistant to new virulent broomrape races. On creation of highly productive sunflower varieties resistant to 
new broomrape races, all parental material during all selection process (nurseries of the $1^{\text {st }}$ and $2^{\text {nd }}$ year of studying preliminary and competitive test, nurseries of the directed pollination) passed an assessment on resistance to broomrape.

In the course of sunflower breeding for heterosis, creation of the self-pollinated lines was done in the field without broomrape during the $1^{\text {st }}$ year, and then, since $\mathrm{J}_{2}$, on the infected plot. On this field between 2500 and 2700 lines of sunflower were sown annually, all of them passing the test on resistance to broomrape. The best varieties according to broomrape-resistance and other traits were exposed to self-pollination or intraliner pollination. By using broomrape-infected plot and applying methods of self-pollination and intraliner pollination, the self- pollinated lines of sunflower VD340, VD342, VD1137, VD53, VD110, VD461, VD62 and VD151 were created. All of them combined high resistance to broomrape with other valuable traits from selection point.

What allowed us to create parental material valuable for breeding practice was continuous control of the parental material to broomrape resistance through estimation of the infected plot in both field conditions and in greenhouse conditions. Simultaneously there was studying in nurseries and reproduction in plots of directed pollination. On this basis such varieties as Don 60, Azovsky, Kazachy, Donskoy, all large-seeded, were developed as well as hybrids such as Donskoy 187, Donskoy 342, Orion, Kaskad, Donskoy 1448, Donskoy 151, Fermer, Mechta, etc., all of them resistant to broomrape.

Application of self-pollination and intervarietal crossings of selected samples allowed us to get complex populations, whose separate biotypes had high mass of 1000 seeds. They almost did not differ from Armenian forms of ecotype (K-1589) according to this indicator. From the point of other economic traits they represented practical interest for selection. As a result of sibling of such biotypes we had separate plants with mass of 1000 seeds $110-160 \mathrm{~g}$ and with low oil content in a kernel. Seeds of the selected plants were sown on the isolated plots and became ancestors of the first Russian large-seeded variety for the confectionary industry the variety "Donskoy large-seeded".

According to the results of comparison among different sunflower varieties, the variety "Donskoy large-seeded" was infected by broomrape race B only on 24.1 and affected only slightly by down mildew, verticilliose and sunflower moth (Table 3). It was also fit for harvesting.

On the basis of the methodical research the scheme of the rapid creation of confectionary sunflower varieties which were resistant to a complex of broomrape races was worked out. In vegetative-climatic chambers of the VNIIMK phytotron elite of Donskoy large-fruited variety were assessed for broomrape resistance and the best performing plants were selected (Klyuka, 1990) during the autumn-winter period. Among the 1000 seeds of Donskoy large-fruited variety given to us for reproduction in 1991, 46 broomrape resistant plants were sorted out during the autumn-winter period and 7 broomrape resistant plants were sorted during winter- 
spring period. Next-year's progenies of the best elite were sown on an infected plot and on the directed pollination plot. As a result of this work it was possible to raise the resistance of Donskoy large-seeded variety to a complex of broomrape races up to $85-95 \%$ in a short time.

Table 3: Results of assessment of Donskoy large-fruited variety to resistance to broomrape and diseases (Donskaya experimental station, 1987-1988).

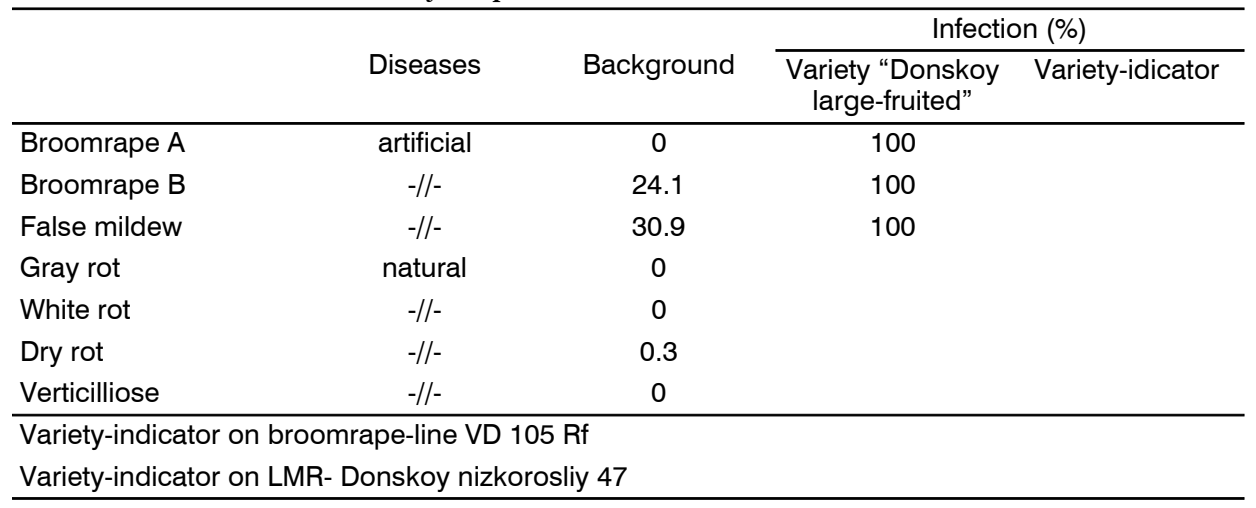

During the years of Perestroyka the work on breeding sunflower resistant to broomrape was weakened. Unjustified expansion of sown areas under sunflower, delivery of seeds of varieties and hybrids that were not checked for the resistance to local broomrape populations, disturbances in crop rotation, excessive interest in surface tillage, etc. all promoted occurrence and distribution of more virulent broomrape races and led to decrease in yield of this valuable oil-bearing crop. During the last few years, only in the Rostov region, the area under sunflower crop is 1.1-1.3 million hectares instead of 450-550 thousand hectares which is the number in accordance with the scientifically-proven systems of agriculture.

Absence of efficient measures to fight broomrape led to the situation where during the years huge stocks of broomrape seeds were collected in soil in the most favourable areas for sunflower cultivation. As they keep the viability for 8-10 years they are capable of infecting the sunflower plants.

The existing situation with sunflower made us assign a field area in a crop rotation creation to a broomrape-infected field. The task for breeders working on the station was to determine percentage and extent of broomrape infected sunflower varieties and hybrids, which were developed in our station and in the other breeder institutions of our country and abroad and which were sown in the Rostov region and in the South Federal district of Russia.

To create the broomrape-infected field we improved the methods and techniques of broomrape plants gathering, their transportation, thrashing, seedcleaning and their storage, and their further use for sowing.

Broomrape seeds were collected from the sowing areas of foreign and domestic selected sunflower varieties and hybrids in Azovky, Kagalnitzky, Zernogradsky, 
Myasnikovsky and Neklinovsky districts of the Rostov region. The collected seeds were united in one sample under the name Parazovskaya. Broomrape seeds collected from the sunflower sowing areas in Morozovsky, Tatzinsky, Konstantinovsky districts were bulked under the name Morozovskaya. To provide even sowing of broomrape seeds on a field we prepared beforehand a working mix of broomrape seeds, sand, soil and fertilizers.

In autumn before sowing of broomrape seeds the field was divided into 4 parts:

1. a plot without broomrape seeds

2. a plot with broomrape seeds of Priazovskaya population

3. a plot with broomrape seeds of Morozovskaya population

4. a plot with broomrape seeds of Morozovskaya and Priazovskaya populations mixture.

During the spring presowing we did cultivation of each part of the field according to the plot and marked areas of $70 \times 70 \mathrm{~cm}$ where seeds of the studied varieties and hybrids were sown. Handing of plants, manual weeding with simultaneous formation of density of plants standing ( 1 plant in a hill), as well as phenological supervision, accounts, measurements were done during plant vegetation.

In year 2009 the total of 137 varieties, hybrids of domestic and foreign development, as well as of Donskaya station breeding, were estimated in the fields infected by populations of broomrape seeds. During the period of sunflower vegetation the "formation of a head-bloom-ripening" was counted with increasing susceptibility of plants varieties, hybrids and lines of sunflower to different broomrape populations.

It has to be noted, that an assessment of 31 varieties and hybrids of sunflower was done in 3 different frequencies on four backgrounds, infected by different broomrape populations.

As Antonova (2009), stated international classification of broomrape races, which today includes races A, B, C, D, E, F, G and H, was accepted. For their recognition it is necessary to test varieties or lines differentiators for each broomrape races. The station doesn't have such samples, therefore at the given stage of the research we use the term "a broomrape population".

Results of an assessment of sunflower varieties and hybrids on various broomrape-infected plots showed different percentages and degrees of infection.

When we compare virulence of Priazovskya and Morozovskaya broomrape populations, almost all studied varieties and hybrids showed smaller percent of infection by Priazovskaya broomrape population. Following varieties had the lowest percentage of infection: Donskoy 60-32\%, Saratovsky $85-34.1 \%$, Saratovsky 2055\%, Maria 15-15.8\%, Spartak-30.7\%, Albatros-33.3\%, Hermes-44.8\%, Kozachy26.2\%, Buzuluk-21.9\%, Lakomka-45.4\%.

On the average, examined varieties and hybrids were infected by Priazovskaya broomrape population at $50.4 \%$ and by Morozovskaya broomrape population at $73.3 \%$ at a degree of infection 6,5 . 
This indicates that Priazovskaya broomrape population has less virulent races in its structure.

Studying of line material for the resistance to this parasitic plant showed, that all lines that had been bred on the station earlier, were infected by broomrape in different degrees. The last quantity of flower stalks of broomrape was found on lines: VD-1448 - with 7.9\% of infection and VD 344 - with $11.6 \%$ of infection. Both were considered earlier to be genetically resistant to broomrape. Line ED 95 - had $16.0 \%$ of infection and line ED 269 - had 26.6\%. Other lines were infected much more severely: VD1137 - 74.5\% of infection, ED $803-77.4 \%$ of infection and VD $151-51.9 \%$ of infection. The test and assessment of a new line material revealed separate line plants which were poorly infected by more virulent Morozovskaya broomrape population (Table 4).

Table 4: Self-pollinated lines, which are best for broomrape resistance (Donskaya experimental station, 2009)

\begin{tabular}{lcc}
\hline Line index & \multicolumn{2}{c}{ Broomrape infection } \\
\cline { 2 - 3 } & $\%$ & degree \\
\hline J-3/227 & 0 & 0 \\
J-3/224 & 0 & 0 \\
$J-3 / 261$ & 0 & 0 \\
$J-3 / 299$ & 25.0 & 1.0 \\
$J-7 / 671$ & 0 & 0 \\
$J-5 / 1276$ & 0 & 0 \\
$J-8 / 1933$ & 12.5 & 2.0 \\
$J-8 / 1910$ & 0 & 0 \\
$J-8 / 1977$ & 16.6 & 4.0 \\
VD 22-control & 100 & 5.0 \\
\hline
\end{tabular}

From these lines there are 4 parent lines (J-3/227, J-3/224, J-3/261, J-3/299) and $5 \mathrm{Rf}$-lines (J-7/671, J-5/1276, J-8/1933, J-8/1910, J-8/1977). In 2008 according to Panchenko's method assessment in greenhouse conditions these lines showed resistance to broomrape. We will continue to work with them.

\section{CONCLUSIONS}

In the future we plan to continue work on creation of parental broomraperesistant material as well as on inspection of sunflower crops in all soil-climatic zones of the region in order to find more virulent races and populations of broomrape.

For reduction of the harmful effect of this parasitic plant on commercial fields in the Rostov region in view of the existing situation the following measures in sunflower cultivation have been developed and offered to farmers:

1. Follow strictly alternation of crops in a crop rotation, returning sunflower crops to a former field every 8-10 years 
2. Limit by administrative measures sunflower cultivation on the area which does not exceed $15 \%$ of the whole arable area (the Regulation of Administration, the Rostov region, No. 182 dated 16.04.2009.)

3. Reduce the surface soil treatment in the fields which will be used under sunflower crops as it leads to accumulation of the infections beginning pathogens, pests, broomrape in the top layer of soil $(0-15 \mathrm{~cm})$ and to replace it with deep ploughing with overturning of layers

4. Fields where crop return is forcedly conducted in the $5^{\text {th }}$ or the $6^{\text {th }}$ year shall be sown with landraces seeds as they are more adapted to local conditions resistant to broomrape

5. Hybrid seeds of foreign selection should be tested for broomrape resistance on infected plot and for illnesses in the research institutions and on the state variety test plots before import to Russia

6. Carry out industrial tests of foreign sunflower hybrids for resistance to herbicides in imidazoline group and to Euro-Light herbicide and also ascertain the financial viability of their cultivation

7. Use binary sowing of sunflower together with legume crops, such as melilot and tare as these crops not only fight broomrape, but also increase sunflower productivity

8. To reduce density of infection of virulent broomrape races in the fields one should sow seeds of varieties and hybrids, which are not resistant to this parasitic plant. At the time of flowering sunflower plants should be mown and could be used as green manure

The research has proven again, that the most reliable and effective method of gaining the parental broomrape-resistant material is breeding on the basis of which varieties and hybrids resistant to more virulent broomrape races and populations are created.

Their introduction into the crop production as well as performance of elementary technologies of cultivation will preserve sunflower as a highly productive and profitable oil-bearing culture.

\section{REFERENCES}

Byalosuknya, V.V., 1919. On the broomrape seeds germination.

Rihter, A.A., 1924. On the physiology of broomrape, which infects sunflower. Works of the Saratov State University (Труды Саратовского Госуниверситета) Edition II.

Nechiporovich, A.A., 1929. On the physiology of Donskaya broomrape. Edition Sevkavkrayzu. Beylin, I., 1930. Broomrape on sunflower and struggle with it. Publishing house "Komuna", Voronezh.

Novopokrovskiy, I.V., 1930. About broomrape in the Astrakhanskiy region. Astrakhan.

Pustovit, V.S., 1926. Brief review of works with oil-bearing sunflower (1912-1925). Works K.Ch. N. Ins. Institute, Krasnodar.

Zhdanov, L.A. 1927. Sunflower and broomrape. Newsletter of Donskaya selection station. Rostov on Don.

Zhdanov, L.A., 1928. On sunflower resistance to broomrape. Magazin, Fat products industry No. 8 . 
Zhdanov, L.A., 1930. Broomrape and sunflower in the north regions of the North Caucuses Region. Magazin, Fat products industry No.3 (56).

Plachek, E.M., Steboot, A.I., 1915. Sunflower (H. annuus L.). Works of the experimental station in the Saratov Region. Saratov, 1915.

Zhegalov, S.I., 1924. Introduction to selection of agriculture plants. Moscow, 1924.

Pustovit, V.S., Dvoryadkin, N.I., 1970. For $80^{\text {th }}$ Anniversary of academician Vashil, L.A. Zhdanov. Bulletin of Agriculture Science No. 3.

Gorbachenko, F.I., Mezinova, V.V., Usatenko, V.V., 1985. Sunflower selection for resistance to broomrape. Oil-bearing plants No. 5.

Gorbachenko, F.I., Shurupov, V.G., 1991. Selection of varieties and hybrids on Don. Scientific and Tehnical Bulletin VNII of oil-bearing plants. Edition No.4.

Panchenko, A.Ya., 1975. Diagnosing of broomrape resistance on early stages of selection and enhancement of sunflower seed-growing. Bulletin of Agriculture Science No. 2.

Antonova, T.S., 2009. Virulence of broomrape on sunflower in the regions of North Caucasus. Bulletin of Russian academy of Agricultural Science. Moscow No. 3.

\section{NOTES:}

\section{Authors of the manuscript}

- Gorbachenko Fedor Ivanovich, Head of selection division, Ph.D. agriculture, professor.

- Usatenko Tatyana Vasiljevna, Junior research scientist,

head of sunflower selection laboratory

- Gorbachenko Oleg Fedorovich, Head of the initial material laboratory,

candidate of agriculture science. 